\title{
Wpływ zmian w komunikaci piśmienniczej na organizację i zbiory biblioteki ekonomicznej (na przykładzie Biblioteki Glównej Uniwersytetu Ekonomicznego w Krakowie)
}

\section{Wprowadzenie}

Drzemiany środków komunikowania stanowią nieodłączny element rozwoju cywilizacyjnego społeczeństw. Niewątpliwie wynalezienie pisma spowodowało wielkie możliwości w sposobie komunikowania, przekazywania myśli w niezmienionej postaci zarówno w czasie, jak i przestrzeni. Pojawienie się książki drukowanej zainicjowało historię nowoczesnych mediów, mimo że początkowo tylko powielano księgi rękopiśmienne. Druk dał sposobność zwielokrotnienia liczby tekstów, umożliwiając jednoczesny odbiór przekazywanych treści. Po około dwustu latach kolejnym przełomem było pojawienie się publikacji periodycznych, docierających do odbiorców dużo szybciej, przekazując opinie i umożliwiając wymianę idei.

Losy środków ludzkiego komunikowania stale ulegają zmianom. Pisze o tym Tomasz Goban-Klas w książce Media i komunikowanie masowe, zestawiając książkę multimedialną z drukowaną i wyciągając wniosek za Wiktorem Hugo: 
Rzecz jasna, książka drukowana nie zginęła i nie zginie, tak jak przetrwały średniowieczne katedry. Jednak funkcje w kulturze i społeczeństwie, podobnie jak katedr, wkrótce ulegną poważnej zmianie. Uznaje się powszechnie, że wiek dwudziesty stał się epoką mediów i komunikowania. Nigdy bowiem w dziejach ludzkości komunikowanie nie miało tylu instrumentów, nie koncentrowało w tak wielkim stopniu uwagi publicznej, nigdy nie stwarzało tak wielkich problemów społecznych, nigdy też nie wiązano z nim tak wielkich nadziei ${ }^{1}$.

Komunikowanie (także komunikowanie się oraz komunikacja społeczna) to termin określający fundamentalny dla istnienia człowieka i społeczeństwa proces wymiany i obiegu informacji. Od kilkuset lat jest uzupełniany przez środki powielania pisma i rysunku (druk), utrwalania obrazu i ruchu (film, fotografia), telekomunikacji (telegraf, telefon, radio i telewizja). Dokonująca się obecnie konwergencja mediów na płaszczyźnie cyfrowej (Internet) oznacza fundamentalną zmianę w charakterze technicznym środków komunikowania².

Wanda Pindlowa, pisząc o zastosowaniach techniki w informacji naukowej, wskazuje na nierozerwalny związek pomiędzy rozwojem informacji naukowej i rozwojem techniki. Istotna rola komunikowania się ludzi wyjaśnia ten związek. Człowiek posługuje się narzędziami umożliwiającymi coraz lepszy przebieg procesu komunikowania, przyspieszając i polepszając jakość informacji. Technika i informacja są sobie nawzajem konieczne ${ }^{3}$.

Coraz powszechniej też podkreśla się potrzebę wykorzystania w nauce nowych technologii i środowisk informacyjno-komunikacyjnych, zwłaszcza narzędzi, usług i zasobów internetowych. Mówi się o efektach i konsekwencjach zastosowania ich w komunikacji naukowej, upowszechnianiu wyników badań czy też coraz łatwiejszej wymianie poglądów wśród naukowców i nawiązywaniu kontaktów ${ }^{4}$.

1 T. Goban-Klas, Media i komunikowanie masowe: teorie i analizy prasy, radia, telewizji i Internetu, Warszawa-Kraków 1999, s. 1-2.

2 Tenże, Komunikowanie i media, [w:] Dziennikarstwo i świat mediów, pod red. Z. Bauera i E. Chudzińskiego, wyd. 4 zm. i uzup., Kraków 2008, s. 11.

3 W. Pindlowa, Zastosowanie techniki w informacji naukowej, [w:] Informacja naukowa w Polsce: tradycja i współczesność, pod red. E. Ścibora, Olsztyn 1998, s. 171.

${ }^{4}$ S. Cisek, Nauka 2.0: nowe narzędzia komunikacji naukowej. W: Konferencja „Informacja w świecie cyfrowym", Dąbrowa Górnicza, 3 marca 2008 r. [on-line]. Dąbrowa Górnicza: Wyższa Szkoła Biznesu, 2008, 21 s. [dostęp 10 sierpnia 2010]. Dostępny w World Wide Web: http://informacjacyfrowa.wsb.edu.pl/pdfs/CisekSabina.pdf. 
Podobnie wielkie znaczenie ma komunikacja w rozwoju nauk ekonomicznych. Stało się to szczególnie ważne, kiedy w nauce ekonomii w Polsce nastąpiły zmiany po 1989 r. Okazało się bowiem, że brakuje nie tylko koniecznej literatury, ale również specjalistyczna terminologia i wiedza nie przystaje do światowej nauki. Wielkim błędem było zaprzepaszczenie doświadczeń polskiej ekonomii okresu międzywojennego, kiedy to wybitni polscy naukowcy w tej dziedzinie stanowili elitę wśród światowych specjalistów. Tymczasem z chęci nasycenia rynku literaturą zachodnią zaczęto tłumaczyć masowo książki stanowiące jedynie formy poradników w stylu ,jak szybko zdobyć fortunę". Ta bezkrytyczna implementacja treści quasi-ekonomicznych wymaga szczególnej rozwagi i doskonałej komunikacji w zakresie omawianych specjalności.

Za potrzebami środowisk naukowych bezwzględnie muszą nadążać biblioteki, zwłaszcza biblioteki akademickie, służące m.in. rozwojowi nauki i badań naukowych, ponieważ główną powinnością biblioteki jest mediacja, „pośrednictwo pomiędzy treściami komunikacji publicznej a społeczeństwem"

\section{Zbiory biblioteczne (od tradycyinych do współczesnych)}

B iblioteki, wypełniając swoje funkcje, gromadzą i upowszechniają dorobek intelektualny. W szeroko rozumianych zasobach bibliotecznych można wyróżnić wydawnictwa zwarte (książki i broszury) i ciągłe (czasopisma, publikacje nieperiodyczne, wydawnictwa seryjne) oraz zbiory specjalne. W tej grupie znajdują się dokumenty tradycyjne (rękopisy, stare druki, kartografia, dokumenty życia społecznego i in.) oraz audiowizualne: oglądowe, słuchowe i oglądowo-słuchowe. Tak skonstruowane, służą polimedialnej komunikacji społecznej, w której biblioteki odgrywają czołową rolę.

Przez wiele lat zasadniczym nośnikiem treści wypełniającym biblioteczne półki były książki i czasopisma. Wielką rewolucję w zakresie gromadzonych zasobów spowodowały media telematyczne, łączące telekomunikację z informatyką. Wszystkie zmiany technologiczne szybko wpływały na pracę i organizację bibliotek. Żywiołowy rozwój technologii informacyjnych i zastosowanie ich w bibliotekach zmienił ich dotychcza-

${ }^{5}$ J. Wojciechowski, Biblioteczna wartość naddana, Kraków 2006, s. 88. 
sowy obraz. W Polsce najszybciej pod tym względem rozwijały się biblioteki wyższych uczelni, działające w środowisku wymagającym natychmiastowego podążania za wszelkimi zmianami. Remigiusz Lis pisze, że „biblioteki podjęły trud automatyzacji i włączają się do globalnego systemu komunikacji, prezentując także na ogólnoświatowym elektronicznym forum swoje zasoby. Owe technologie, traktowane zrazu jako jedynie wsparcie, otoczka dla powtarzalnych elementów procesów bibliotecznych, zastępują z wolna analogowy sposób ich dokumentacji”'

\section{Zmiany w zasobach i organizaci biblioteki}

7 biory stanowią podstawę istnienia każdej biblioteki. W Bibliotece GGłównej Uniwersytetu Ekonomicznego w Krakowie (dalej: BG UEK) zasadniczy trzon kolekcji tworzą zasoby związane z kierunkiem kształcenia uczelni. Księgozbiór trafiający do biblioteki w okresie międzywojennym pochodził z wielu różnorodnych źródeł, były to dary z prywatnych kolekcji, ze zlikwidowanego Studium Spółdzielczego przy Uniwersytecie Jagiellońskim, a także z licznych instytucji i urzędów. Te zbiory zasługują na specjalną troskę i zainteresowanie. Aby ułatwić dostęp do nich, w bibliotece zdigitalizowano najstarsze katalogi: klamrowy i kartkowy oraz umieszczono je w Internecie.

Przez wiele lat gromadzono przede wszystkim książki i czasopisma z szeroko rozumianych nauk ekonomicznych i towaroznawczych, a także prawa, nauk społecznych i dziedzin pokrewnych. Obecnie zakres ten poszerza się, co ma związek z otwieraniem nowych kierunków studiów, takich jak np. turystyka i rekreacja czy też informatyka stosowana. Biblioteka jest też w posiadaniu kilkunastu tysięcy norm dotyczących towaroznawstwa spożywczego i przemysłowego.

Zmiany ustrojowo-systemowe w kraju wpłynęły zdecydowanie na literaturę $\mathrm{z}$ dziedziny ekonomii. $\mathrm{W}$ programach nauczania przestały obowiązywać dotychczas uznawane publikacje. W związku z tym w BG UEK księgozbiór biblioteczny poddawano zdecydowanej selekcji. Ze zbiorów usunięto blisko 50 tys. woluminów, pozostawiając egzemplarze mogące służyć badaniom porównawczym. Lukę powstałą na skutek znacznej wy-

${ }^{6}$ R. Lis, Od druku do bitów, czyli o digitalizacji systemów bibliotecznych. Biuletyn EBIB [on-line] 2006, nr 4 (74) [dostęp 10 sierpnia 2010]. Dostępny w World Wide Web: http://ebib.info/2006/74/lis.php. 
miany druków zastąpiły teksty na nowoczesnych, elektronicznych nośnikach.

Obecnie dotychczasowa organizacja wielu bibliotek sukcesywnie ulega zmianom. Zwiększa się grupa materiałów w postaci cyfrowej, w stosunku do których obowiązują nowe wzorce pozyskiwania. „Dane stają się osiągalne dzięki licencji i nie są wypożyczane"7. Coraz częściej mówi się o konieczności łączenia oddziałów gromadzenia z opracowaniem, opracowania formalnego z rzeczowym, swobodnego poruszania się użytkowników wśród wszystkich zasobów biblioteki. „Mówimy nie tyle o gromadzeniu, co o organizacji dostępu, i nie tyle o zbiorach, co o zasobach. Nie oznacza to, że pojęcia: gromadzenie i zbiory wyrzuciliśmy z naszego bibliotekarskiego słownika. Jednak nowe określenia lepiej oddają ducha przemian"8.

Zmiany nie ominęły także BG UEK. Przekształceniu uległa organizacja pracy całej biblioteki, począwszy od gromadzenia i opracowania, do informacji, udostępniania i przechowywania zbiorów. Obecnie tradycyjna kolekcja jest uzupełniana z dużym natężeniem o wydawnictwa elektroniczne: CD-ROM-y, pliki, multimedia, bazy dostępne wyłącznie on-line. Stale rośnie też liczba czasopism elektronicznych.

Pojawienie się w bibliotece nowych dokumentów wymagało również natychmiastowej rejestracji wpływów i utworzenia wydzielonych ksiąg inwentarzowych. Do inwentaryzowania e-źródeł, podobnie jak książek i czasopism, wykorzystuje się w BG UEK własny program komputerowy. Początkowo było to trudne zadanie, powodujące problemy związane choćby ze zmianą nośnika przez producenta w ciągu jednego roku kalendarzowego, ponieważ w myśl obowiązującego rozporządzenia Ministerstwa Kultury układ inwentarza winien być zgodny z rodzajem nośnika. Stworzono też „Rejestr Dokumentów Niematerialnych” zbudowany z tych

${ }^{7}$ G. Piotrowicz, Cyfrowa przyszłość, czyli biblioteki w erze informacji. W: II Konferencja Biblioteki Politechniki Łódzkiej „Biblioteki XXI wieku. Czy przetrwamy?”, Łódź 19-21 czerwca 2006 r. [on-line]. [Warszawa]: Stowarzyszenie Bibliotekarzy Polskich, Komisja Wydawnictw Elektronicznych, Politechnika Łódzka, 2009, 20 s. (EBIB Materiały konferencyjne, nr 16) [dostęp 10 sierpnia 2010]. Dostępny w World Wide Web: http:// ebib.info/publikacje/matkonf/biblio21/sesja6ref2.pdf.

${ }^{8}$ A. Jazdon, Problematyka organizacji zasobów w nowoczesnej bibliotece akademickiej. W: Ogólnopolska Konferencja Naukowa „Nowoczesna Biblioteka Akademicka”, Olsztyn, 20-21 maja $2004 r$. [on-line]. [Warszawa]: Stowarzyszenie Bibliotekarzy Polskich, Komisja Wydawnictw Elektronicznych, 2004 (EBIB Materiały konferencyjne, nr 9) [dostęp 10 sierpnia 2010]. Dostępny w World Wide Web: http://ebib.oss.wroc.pl/matkonf/nba/jazdon.artur.php. 
samych elementów co inwentarze, gdyż zasadne wydawało się rejestrowanie i kontrolowanie wydatków ponoszonych na zakup kosztownych źródeł informacji, jakimi są hasła dostępu do baz.

\section{Zmiany w zakresie opracowywania zbiorów}

Z miany organizacyjne związane z pojawieniem się nowych technologii chyba najwcześniej objęły oddziały opracowujące wydawnictwa tradycyjne. Już z początkiem lat 90. XX w. w BG UEK zaczęto tworzyć opisy katalogowe książek w systemie MAK. Początkowo prowadzono prace dwutorowo, tworzono opisy komputerowe, ale i tradycyjne karty katalogowe. Po niedługim czasie biblioteka przystąpiła do ogólnopolskiego zespołu bibliotek współtworzących Centralny Katalog Haseł Wzorcowych i rozpoczęła katalogowanie zbiorów w systemie VTLS. BG UEK była też w pierwszej grupie bibliotek przystępujących do tworzenia katalogu NUKAT. Obecnie całość nowo nabywanych zbiorów jest wprowadzana do tego katalogu. Sukcesywnie są też prowadzone prace związane z retrokonwersją, która dotyczy przede wszystkim cennych zbiorów, a także pozycji najczęściej poszukiwanych przez użytkownika.

Z chwilą pojawienia się formatu MARC 21 i normy dla dokumentów elektronicznych PN-N-01152-13 (Opis bibliograficzny. Dokumenty elektroniczne) natychmiast przystąpiono do tworzenia opisów bibliograficznych dla tej grupy dokumentów i wprowadzania ich do OPAC-u. Nie jest to jedyna instrukcja obowiązująca przy katalogowaniu zbiorów elektronicznych. W przypadku katalogowania e-książki, e-mapy czy e-czasopisma stosuje się jednocześnie instrukcję katalogowania dla odpowiedniej grupy dokumentów. Zasób tego rodzaju zbiorów bibliotecznych sukcesywnie powiększa się z roku na rok.

\section{Gromadzenie kolekcii wydzielonych}

$D^{\prime}$ a poszerzenia oferty i wzbogacenia zasobów biblioteki ogromne znaczenie mają kolekcje depozytowe. Już w 1993 r. BG UEK uzyskała z Centrum Zadłużenia i Rozwoju depozyt, który w zbiorach funkcjonuje jako Biblioteka Depozytowa Banku Światowego. W skład kolekcji wchodzą serie wydawnicze, monografie, czasopisma oraz dokumenty elektroniczne. 
W wyniku innej inicjatywy i starań pozyskano także depozyt Międzynarodowego Funduszu Walutowego (International Monetary Fund), z którego utworzono Bibliotekę Depozytową Międzynarodowego Funduszu Walutowego. Dzięki aneksowi do umowy niektóre publikacje z tego zasobu udostępnia się również w lokalnej sieci komputerowej.

Kolejny depozyt wpłynął do biblioteki w 2005 r. Stanowi on cenne uzupełnienie zawartości tematycznej wcześniejszych oraz wsparcie studiów nad transformacją gospodarki Polski i innych europejskich krajów postkomunistycznych. Biblioteka Depozytowa Europejskiego Banku Odbudowy i Rozwoju (dalej: EBOR) (powstała na mocy wspomnianego depozytu) obejmuje publikacje tematycznie związane z bieżącą działalnością EBOR, a więc działania zmierzające do podtrzymania procesu transformacji, rozwoju zasad demokracji, pluralizmu i gospodarki rynkowej w krajach Europy Środkowej i Wschodniej. Część dokumentów jest udostępniana w sieci lokalnej (wydawca zezwolił na gromadzenie i udostępnianie w Intranecie dokumentów elektronicznych ze strony EBOR) ${ }^{9}$.

W 1995 r. na mocy porozumienia między Dyrektorem Generalnym Komisji Europejskiej a Rektorem Akademii Ekonomicznej powstało przy bibliotece Centrum Dokumentacji Europejskiej. Otrzymuje ono nieodpłatnie publikacje Wspólnot Europejskich, tj. książki, czasopisma, opracowania, raporty, statystyki, przeglądy dokumentacyjne itp. Tematyka zbiorów zdecydowanie wspiera profil gromadzonej kolekcji o zagadnienia handlu międzynarodowego, finansów, polityki społecznej, prawa, przemysłu, transportu, pracy, ochrony środowiska i statystyki ${ }^{10}$. W kolekcji centrum znaczące miejsce zajmują zbiory nabywane przez bibliotekę, a związane tematycznie z szeroko pojętą problematyką Unii Europejskiej.

\section{Konsorcja - nowa forma wspólpracy bibliotek}

$B$ iblioteki, przed którymi coraz więcej wyzwań i oczekiwań stawianych zarówno przez wymagających użytkowników, jak i nie mniej wyma-

${ }^{9}$ Biblioteka Depozytowa EBOR [on-line]. Biblioteka Główna Uniwersytetu Ekonomicznego w Krakowie [dostęp 10 sierpnia 2010]. Dostępny w World Wide Web: http:// kangur.uek.krakow.pl/biblioteka/ebor/.

${ }^{10}$ Centrum Dokumentacji Europejskiej przy Bibliotece Głównej Uniwersytetu Ekonomicznego w Krakowie [on-line]. Biblioteka Główna Uniwersytetu Ekonomicznego w Krakowie [dostęp 10 sierpnia 2010]. Dostępny w World Wide Web: http://kangur.uek.krakow.pl/biblioteka/cde/. 
gające władze, nawiązują coraz ściślejszą współpracę. „Pojawiły się mianowicie zadania trudne lub wręcz niemożliwe do realizacji siłami jednej biblioteki"11. Niebagatelne znaczenie w podejmowaniu współpracy mają też względy ekonomiczne, drastyczna redukcja budżetów, a także rosnąca liczba studentów. Efektem tych działań stają się organizacje typu konsorcyjnego. Temat konsorcjów został szeroko omówiony przez Grażynę Piotrowicz w artykule Konsorcja bibliotek uczelnianych - wczoraj, dziś, jutro. Autorka pisze w nim, że konsorcja

powinny nie tylko negocjować archiwizowanie, jako część licencji, ale również pracować wspólnie nad ułatwianiem tworzenia i utrzymywania efektywnych składnic archiwalnych. Konsorcja muszą podjąć kroki, aby archiwizować informacje, które kupują lub na które uzyskują licencje, i aby mieć zagwarantowaną przez dostawcę wieczystą licencję raczej na zakup informacji, niż ich dzierżawę, jeśli dane są lokalnie posadowione na serwerze lub dostępne przez stronę $\mathrm{Web}^{12}$.

Autorka podkreśla też konieczność uzyskania nieograniczonego dostępu do informacji.

BG UEK do współpracy konsorcyjnej przystąpiła bardzo szybko, bo już w 2001 r., kiedy to zostało powołane Konsorcjum Bibliotek Kierunków Ekonomicznych. Jego celem jest pozyskiwanie i wdrażanie elektronicznych nośników informacji, a poprzez zbiorowy zakup i możliwość negocjowania cen z producentami - uzyskiwanie możliwości znacznego obniżania kosztów nabywania nowych źródeł informacji. Również instytucje dofinansowujące biblioteki chętniej partycypują w kosztach zakupów dla zrzeszonej w ramach konsorcjum grupy bibliotek.

\section{Bazy fworzone w BG UEK}

B ez wątpienia bardzo duże znaczenie dla użytkowników w umożliwianiu szerszego dostępu do wiedzy w zakresie badań ekonomicznych i gospodarczych miało pojawienie się w ofercie BG UEK baz danych two-

${ }^{11}$ J. Wojciechowski, dz. cyt., s. 51.

12 G. Piotrowicz, Konsorcja bibliotek uczelnianych - wczoraj, dziś, jutro. Biuletyn EBIB [on-line] 2002, nr 7 (36) [dostęp 10 sierpnia 2010]. Dostępny w World Wide Web: http:// ebib.oss.wroc.pl/2002/36/piotrowicz.php. 
rzonych przez pracowników biblioteki. Ogromny niedobór literatury ekonomicznej, odczuwany przez czytelników, starano się uzupełniać poprzez tworzenie opisów artykułów zamieszczanych w wiodących czasopismach ekonomicznych oraz seriach wydawniczych wszystkich uczelni ekonomicznych w Polsce, Instytutu Nauk Ekonomicznych PAN, Instytutu Badań nad Gospodarką Rynkową czy Centrum im. Adama Smitha. Powstałe w ten sposób bazy „Gospodarka” i „Nauki Społeczne” - stale uzupełniane i aktualizowane - funkcjonują do chwili obecnej. Dodatkowe źródło informacji tworzone w BG UEK stanowią także bazy:

- „Dorobek” - baza informująca o dorobku naukowym pracowników uczelni,

- „Nobliści” - baza rejestrująca laureatów Nagrody Nobla w dziedzinie ekonomii,

- „Zastosowania Informatyki” - bieżąca, adnotowana bibliografia, której głównymi obszarami zainteresowań są: programowanie, wspomaganie pracy biurowej, rozwiązywanie problemów związanych $\mathrm{z}$ komputerem, najnowsze rozwiązania informatyczne oraz programy edukacyjne.

Popularność wykorzystania baz własnych BG UEK prezentuje wykres 1.

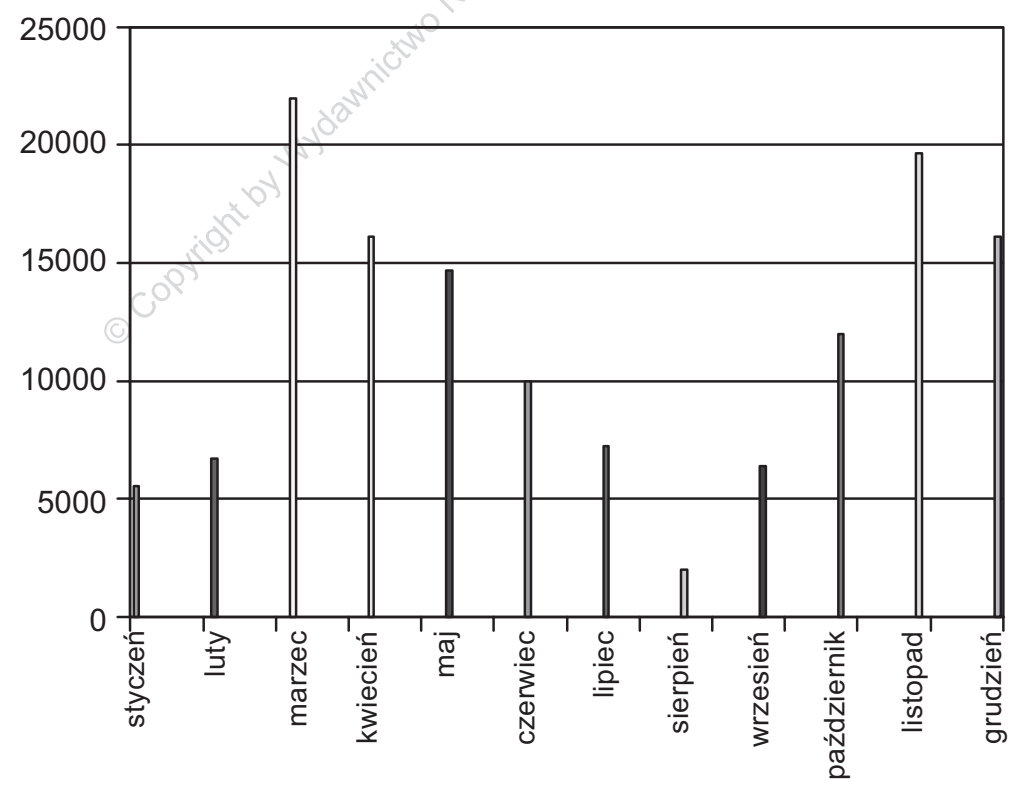

Wykres 1. Liczba wejść do baz własnych w 2009 r.

Źródło: opracowanie własne. 


\section{Informacja tradycyjna a elektroniczna}

Dojawienie się nowych sposobów zapisywania danych zapoczątkowało Rolejny rozdział w działalności informacyjnej bibliotek. Nowe możliwości dostarczania i przekazywania informacji czytelnikom i użytkownikom stały się coraz bardziej dostępne, a zastępowanie dostępu lokalnego modelem dostępu globalnego - coraz powszechniejsze.

Dotychczasowa informacja organizowana dzięki posiadanym przez bibliotekę, fizycznie istniejącym kolekcjom jest zastępowana organizowaniem szerokiego dostępu do zbiorów gromadzonych w licznych bazach, portalach i zasobach cyfrowych. W działalności informacyjnej BG UEK z początkiem lat 90. zaczęły następować zdecydowane zmiany. Użytkownicy zaczęli chętniej sięgać do elektronicznych źródeł informacji, ceniąc szybkość wyszukiwania czy też możliwość sprawnego pobierania informacji i zapisywania na własnych nośnikach bądź wysyłania pocztą elektroniczną. Obserwuje się ograniczanie czasu spędzanego przez czytelników w budynku biblioteki do niezbędnego minimum. Wśród użytkowników powstaje opisany przez Marię Próchnicką syndrom „lenistwa informacyjnego", przejawiającego się pomijaniem źródeł spoza sieci ${ }^{13}$.

Wraz z upowszechnieniem dostępu do Internetu pojawiły się kolejne możliwości, ale i kolejne zagrożenia. Niebezpieczne stało się traktowanie znajdowanych tam przekazów jako bezwzględnie wiarygodnych i nierzadko jedynych informacji. „Oprócz treści ważnych są w nim [Internecie - przyp. D. D.] też informacyjne oraz nieinformacyjne śmieci. To stwarza nowe wyzwania, tak w zakresie porządkowania, opracowania i przygotowania informacji o tych zasobach, jak też w zakresie ich archiwizacji"14 pisze Jacek Wojciechowski. Podejmując prace nad porządkowaniem informacji z dziedziny ekonomii, w BG UEK stworzono serwis tematyczny - Ekonomia on-line (rys. 1), kierujący użytkowników zainteresowanych zagadnieniami ekonomicznymi do internetowych źródeł informacji. Wyszukiwaniem i opracowywaniem źródeł, oceną ich przydatności i aktualizacją danych zajmują się wyłącznie pracownicy biblioteki.

${ }^{13}$ M. Próchnicka, Pojęcie i specyfikacja elektronicznych źródeł informacji, [w:] Przestrzeń informacji i komunikacji społecznej, pod red. M. Kocójowej, Kraków 2004, s. 56.

${ }^{14}$ J. Wojciechowski, dz. cyt., s. 98. 


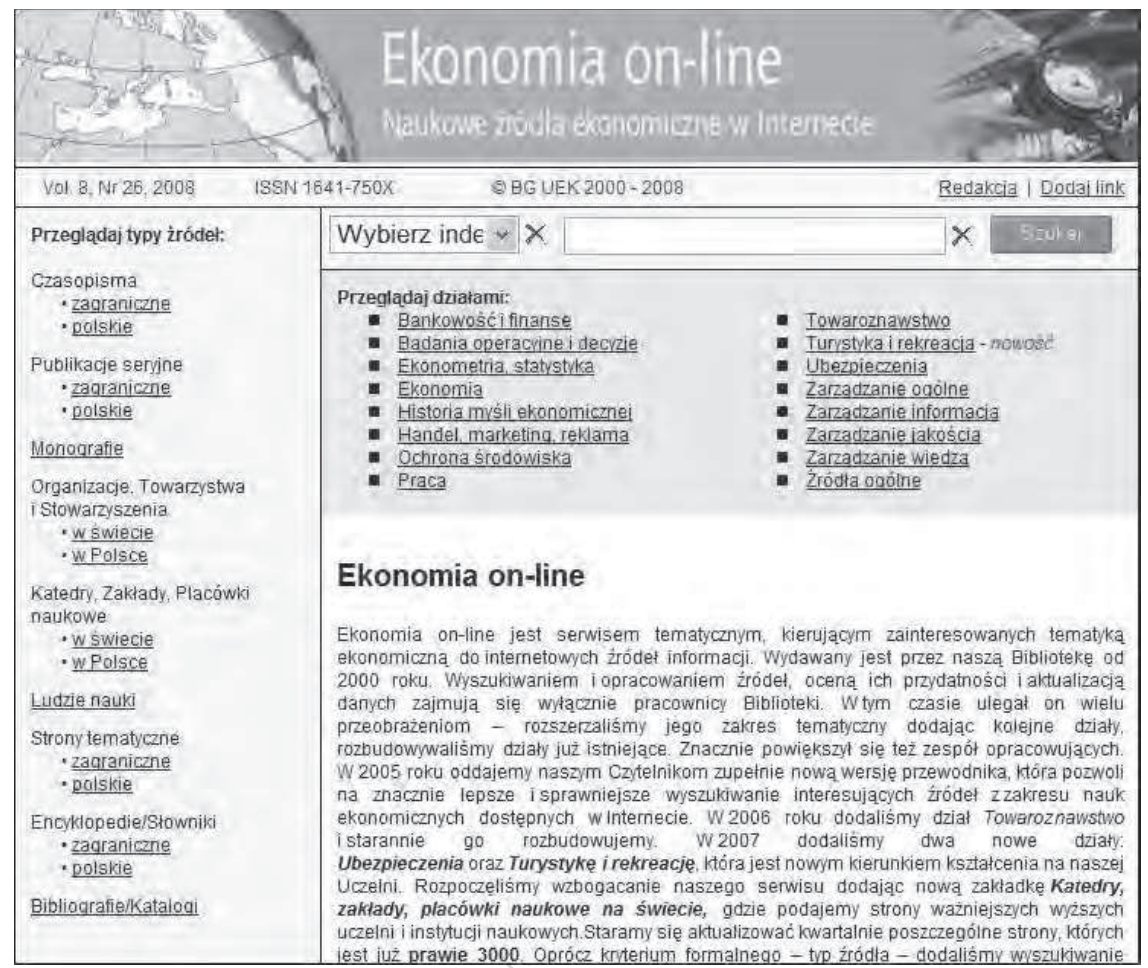

Rysunek 1. Serwis Ekonomia on-line

Źródło: Ekonomia on-line. Naukowe źródła ekonomiczne w Internecie [on-line]. Biblioteka Główna Uniwersytetu Ekonomicznego w Krakowie [dostęp 10 sierpnia 2010]. Dostępny w World Wide Web: http://kangurold.uek.krakow.pl/Biblioteka/Ekonomia/.

\section{Digitalizacja zbiorów w BG UEK}

Mciągu ostatnich kilku lat obserwuje się natężenie prac związanych z digitalizacją zbiorów przeprowadzana przez wiele polskich bibliotek. Początkowo były to inicjatywy realizowane w poszczególnych placówkach. Obecnie coraz powszechniejsze stają się projekty wdrażane w ramach regionów lub grupy bibliotek, cenne ze względu na poszerzanie dostępu on-line do licznych źródeł informacji. W BG UEK potrzebę digitalizacji dostrzeżono bardzo wcześnie, bo już w 2002 r. Rozpoczęto wówczas udostępnianie w formie cyfrowej najcenniejszych i najstarszych książek. W chwili obecnej biblioteka współpracuje w tym zakresie w ramach Akademickiej Biblioteki Cyfrowej. 


\section{Podsumowanie}

becna organizacja BG UEK, jak również struktura jej zbiorów świadczą o tym, że podobnie jak większość bibliotek akademickich, placówka ta staje się biblioteką hybrydową, łączącą elementy biblioteki elektronicznej z biblioteką tradycyjną. Dzięki spopularyzowaniu nowoczesnych mediów komunikowania pojawił się nowy wymiar możliwości informacyjnych biblioteki. Wymaga on jednak coraz większego zaangażowania sił, umiejętności i środków. Podobnie jak inne biblioteki, także BG UEK będzie zapewne w dalszym ciągu rozwijała się w kierunku wielokomunikacyjności, starając się pogodzić i połączyć różnorodne źródła informacji, by w ten sposób zapewnić użytkownikowi jak najbardziej kompletną obsługę.

\section{The impact of changes in written communication on economics library organization (Main Library of Cracow University of Economics example) Abstract}

Changes in written communication proved to have significant impact on the libraries' work organization and the process of collection management. The article presents the changes in the library information framework resulting from the introduction of new communication media. Polish socio-economic transition brought the need for weeding the library's collection and was the driving force behind the application of new information technologies to fill the gaps in appropriate economic resources. A quick response to those arising needs led to a development of several proprietary databases by our library staff. These databases, constantly updated and expanded, are still a valuable source of information. This paper concentrates on the evolution and functioning of the hybrid structure of our library, where new media sources continuously complement traditional print materials. Finally, the article discusses different levels of transformation related to the library's activities, from collection development to scientific and scholarly information services. 